\title{
LIETUVOS DIDŽIŲJŲ MIESTŲ 5-11 KLASIŲ MOKSLEIVIŲ SU SVEIKATA SUSIJĘS FIZINIS AKTYVUMAS
}

Vida Volbekienè, Aušra Griciūtè, Aida Gaižauskienè Lietuvos kūno kultūros akademija, Kaunas, Lietuva

\begin{abstract}
Vida Volbekienė. Docentẻ socialinių mokslų daktarẻ. Lietuvos kūno kultūros akademijos Kūno kultūros ir sporto teorijos katedros vedẻja. Mokslinių tyrimų kryptis — sveikata, fizinis aktyvumas.
\end{abstract}

\section{SANTRAUKA}

Tyrimo tikslas — nustatyti su sveikata susijusio fizinio aktyvumo paplitima tarp Lietuvos didžiuju miestu 5-11 klasiu moksleiviu.

Tyrimas atliktas 2005 metu balandžio mènesi penkiuose didžiuosiuose Lietuvos miestuose (Vilniuje, Kaune, Klaipédoje, Siauliuose, Panevéžyje). Pagal 2001 metu Lietuvos gyventoju surašymo duomenis nustatytas 11-18 metu amžiaus asmenu imties dydis lyties ir amžiaus grupesse. Mokyklos pasirinktos atsitiktinai. Mokiniai pagal klases mokyklose buvo atrenkami patogiosios atrankos būdu. Analizuojant su sveikata susijusio fizinio aktyvumo rezultatus, tiriamaja imti sudare 1636 mokiniai.

Moksleiviu fizinis aktyvumas (FA) nustatytas pagal modifikuota tarptautini FA (IPAQ) klausimynq. Patiriantys sveikata stiprinanti fizini aktyvuma (SSFA) buvo laikomi tie mokiniai, kuriu FA intensyvumas vidutinis, trukmè 60 min, dažnis - kiekvienq dienq. Kiti moksleiviai dèl nepakankamo fizinio aktyvumo turi galimybe patirti sveikatos rizikos grésmę (WHO, 2003). Anketinę apklausq vykdè penkios specialiai parengtos kvalifikuotu tyrëju grupès.

Naudoti šie statistinès analizès metodai: kintamuju dažnis ir procentai; kintamuju vidurkis; standartinis nuokrypis; $t$ kriterijus; chi kvadrato kriterijus; pasikliaunamieji intervalai; Spirmeno ranginès koreliacijos koeficientas; Somerio $d$ koeficientas. Statistinès analizès metu naudotos SPSS ir Excel programos.

Išvados: iš viso SSFA patiria tik 14,2\% Lietuvos didžiuju miestu 5-11 klasiu moksleiviu, o lyties grupèse - 9,8\% mergaičiu ir 18,6\% berniuku. SSFA büdingesnis berniukams nei mergaitèms $\left(\chi^{2}=26,5 ; p<0,001\right)$. Dèl nepakankamo SSFA galimybe patirti sveikatos sutrikimo rizikos grèsme turi 90,2\% mergaičiu ir $81,4 \%$ berniuku, iš viso $85,8 \%$ moksleiviu (WHO, 2003).

Tiek mergaičiu, tiek berniuku, patiriančiu su sveikata susijusi fizini aktyvuma, skirstiniai ir pagal klases, ir pagal gyvenamaja vieta statistiškai reikšmingai nesiskiria. Mergaičiu, kurioms būdingas SSFA fizinio pasyvumo (sèdèjimo) per dienq trukmé, nors ir nedaug, tačiau yra mažesne už mergaičiu, kurios nepatiria SSFA. Tarp berniuku, patiriančiu ir nepatiriančiu SSFA, statistiškai reikšmingas skirtumas tarp ju fizinio pasyvumo trukmès nenustatytas.

Raktažodžiai: su sveikata susijęs fizinis aktyvumas, fizinis aktyvumas, fizinis pasyvumas.

\section{IVADAS}

$\mathrm{K}$ asdienis vaikų fizinis aktyvumas yra būtinas jų normaliam augimui ir vystymuisi, naudingas ju sveikatos prevencijai, fiziniam pajègumui (Barnekow-Bergkvist et al., 1998; Casperson et al., 1998; Katzmarzyk et al., 1999; Barnekow-Bergkvist et al., 2001). Dažniausiai fizinis aktyvumas yra siejamas su fizine sveikata, tačiau pastaraisiais metais vis labiau atkreipiamas dẻmesys i paauglių fizinio aktyvumo lygio, psichologinių ir socialinių sveikatos dimensijų ryši.
Naujausiais tyrimų duomenimis, fizinio pasyvumo ar aktyvumo kilmè yra nulemta biologiškai. Fizinio aktyvumo raišką lemia paveldimumas, jo veiksnių itaka. Manoma, kad fizinis aktyvumas ypač svarbus vaikų protinei ir socialinei raidai, tačiau tai irodyti trukdo metodologinès fizinio aktyvumo nustatymo problemos (Biddle et al., 2004; Andersen, Mechelen, 2005).

Egzistuoja daugybė fizinio aktyvumo formu, kurias rekomenduoja atskiri mokslininkai arba 
1 lentelè. Tiriamosios imties apibūdinimas: skirstinys pagal miestus

\begin{tabular}{|l|l|l|l|}
\hline \multirow{2}{*}{ Miestas } & \multicolumn{2}{|l|}{ Tiriamoji imtis } & Planuotos reprezentatyvios tiriamosios imties \\
\cline { 2 - 4 } & $\mathrm{N}$ & $\%$ & sandai, \% \\
\hline Vilnius & 675 & 39,6 & 39,3 \\
\hline Kaunas & 453 & 26,6 & 26,5 \\
\hline Klaipėda & 243 & 14,3 & 14,6 \\
\hline Šiauliai & 169 & 9,9 & 10,4 \\
\hline Panevėžys & 164 & 9,6 & 9,2 \\
\hline Iš viso & 1704 & 100 & 100 \\
\hline
\end{tabular}

2 lentelè. Tiriamosios imties apibūdinimas: skirstinys pagal lytị ir klases

\begin{tabular}{|c|c|c|c|c|c|}
\hline \multirow{3}{*}{ Klasė } & \multicolumn{4}{|c|}{ Tiriamoji imtis } & \multirow{3}{*}{$\begin{array}{l}\text { Planuotos reprezentatyvios } \\
\text { tiriamosios imties sandai, } \%\end{array}$} \\
\hline & \multirow{2}{*}{$\begin{array}{l}\text { Berniukai } \\
\left(\mathrm{N}^{\mathrm{B}}\right)\end{array}$} & \multirow{2}{*}{$\begin{array}{l}\text { Mergaitès } \\
\left(\mathrm{N}^{\mathrm{M}}\right)\end{array}$} & \multicolumn{2}{|c|}{ Bendra tiriamoji imtis } & \\
\hline & & & $\mathrm{N}$ & $\%$ & \\
\hline 5 & 114 & 118 & 232 & 13,7 & 13,4 \\
\hline 6 & 121 & 128 & 249 & 14,6 & 15,3 \\
\hline 7 & 119 & 130 & 249 & 14,5 & 14,5 \\
\hline 8 & 139 & 128 & 267 & 15,7 & 15,5 \\
\hline 9 & 119 & 116 & 235 & 13,8 & 13,7 \\
\hline 10 & 128 & 107 & 235 & 13,8 & 13,6 \\
\hline 11 & 108 & 129 & 237 & 13,9 & 14,0 \\
\hline Iš viso & 848 & 856 & 1704 & 100 & 100 \\
\hline
\end{tabular}

tam tikrai institucijai atstovaujančių ekspertų grupè. Didžiausio dèmesio sulaukia ekspertu grupiu parengtos skirtingos paskirties rekomendacijos (pvz., atskirų ligu prevencijos, sveikatos stiprinimo, sveiku asmenų elgsenos kaitos ir pan.) (Corbin et al., 2002). Šiame straipsnyje autoriai vadovaujasi ekspertu rekomendacijomis, kurios labiausiai susijusios su vaikų ir paauglių elgsenos kaita pabrèžiant sveikatą stiprinančio fizinio aktyvumo intensyvumą, trukmę ir dažnumą: vidutinio intensyvumo (t. y. išeikvojant $6-8 \mathrm{kcal} / \mathrm{kg}$ per dieną), ne mažesnis kaip 60 minučiu trukmès fizinis aktyvumas kiekvieną dieną (Sallis et al., 1994; USDHHS, 1996; ACSM, 2002; National Association for Sport and Physical Education, 2003). Nepatiriant tokio sveikatą stiprinančio fizinį aktyvumo, iškyla sveikatos sutrikimo rizikos grèsmè dèl mažo fizinio aktyvumo (WHO, 2003).

Šiuo metu aktualūs fizinio aktyvumo ir atskirų sveikatos komponentų dozès - atsako ryšio, optimalios intervencijos $\mathfrak{i}$ vaiku ir jaunimo fizini aktyvuma - tyrimai (Hardman, 2001; Rankinen, Bouchard, 2002; Oja, Borms, 2004). Lietuvoje per pastaruosius penkerius metus reprezentatyviu tyrimų, tiesiogiai susijusių su Lietuvos moksleivių sveikatą stiprinančiu fiziniu aktyvumu, rasti nepavyko.

Tyrimo tikslas - nustatyti su sveikata susijusio fizinio aktyvumo paplitimą tarp Lietuvos didžiujų miestų 5-11 klasių moksleivių. Tyrimo objektas - su sveikata susijęs fizinis aktyvumas.

\section{TYRIMO METODAI}

Tyrimo imties planavimas ir atranka (Гудвин, 2004). Tyrimai buvo atliekami 2005 metų balandžio mèn. penkiuose didžiuosiuose Lietuvos miestuose (Vilniuje, Kaune, Klaipèdoje, Šiauliuose, Panevèžyje). Pagal 2001 metų Lietuvos gyventojų surašymo duomenis nustatytas $11-18$ metų amžiaus imties dydis lyties ir amžiaus grupèse. Suplanuotas bendrosios nacionalinès imties dydis - 2048 respondentai. Bendrojo lavinimo vidurinių mokyklų, reprezentuojančių 5 didžiuosius Lietuvos miestus, atrankoje nedalyvavo šios mokyklos: labai didelès (patenkančios i̇ 10\% didžiausiuju mieste), labai mažos (patenkančios i $10 \%$ mažiausiuju mieste), specialiosios (pvz., profesinès, nacionaliniu mažumu), esančios miesto periferijoje. Likusios mokyklos atrinktos atsitiktinai, iš kiekvieno miesto rajono atrenkant po vieną. Buvo atrinkta 14 mokyklų: Vilniuje -6 , Kaune - 4, Klaipèdoje -2 , Šiauliuose ir Panevėžyje po 1.

Mokiniai pagal klases mokyklose buvo atrinkti patogiosios atrankos būdu, t. y. apklausiami atsižvelgiant i jų pamokų tvarkarašti ir mokyklos administracijos sudarytas galimybes. Kadangi klasė ir mokiniu amžius, atliekant statistinę analizę, iš esmès yra lygiaverčiai (tarp klasės ir mokinių amžiaus nustatyti stiprūs koreliaciniai ryšiai, Spirmeno koeficientas lygus 0,97), statistinè duomenu analizè atlikta lyties ir klasès grupèse, nes klasè geriau atitinka tyrimo imties planavimą. Iš viso apklausta 2243 mokiniu. 
Tiriamoji imtis buvo sumažinta atsižvelgiant i šiuos kriterijus: pastebėtą klaidų ir neatsakytu klausimu skaičiu anketose. Šitaip tiriamosios imties dalių tarpusavio proporcijos buvo priartintos prie tiriamos populiacijos proporciju, ir padidejo duomenu patikimumas ir kokybè. Skirtumas tarp atskiru miestų faktinès ir planuotos reprezentatyvios tiriamosios imties pagal miestus - mažesnis už $0,5 \%$ (1 lent.), o pagal klases (berniuku ir mergaičių atskirai) - mažesnis už $0,7 \%$ (2 lent.). Gautoji imtis buvo sąlygiškai pavadinta nacionaline (didžiujų miestų bendrojo lavinimo vidurinių mokyklų) imtimi. Nacionalinę didžiujų miestų imti sudare 1704 mokiniai. Straipsnyje analizuojami su sveikata susijusio fizinio aktyvumo rezultatai, todèl iš nacionalinès imties buvo išskirti 1636 tiriamieji, kurių anketose pateikti visi su sveikata susijusio fizinio aktyvumo skaičiavimui reikalingi duomenys.

Metodika. Moksleiviu fizinis aktyvumas (FA) nustatytas pagal modifikuotą tarptautini FA (IPAQ) klausimyną (Ainsworth, Levy, 2004). Anketą sudaro keturios dalys, pagal kurias buvo surinkti duomenys apie: I. Didelį FA — didelių fizinių pastangų, dažnumas - dienų skaičius per savaitę, trukmè - vienu metu daugiau nei 10 minučių; II. Vidutini FA — vidutinès fizinès pastangos, dažnumas - dienų skaičius per savaitę, trukmè - vienu metu daugiau nei 10 minučių; III. Ėjimo dažnumą per savaitę; IV. Sèdèjimo trukmę per dieną. Kiekvieną dalị, išskyrus IV, sudaro 3 klausimai, nustatantys I ir II dalies FA trukmę ir jo dažnumą, III dalies - ejjimo intensyvumas, trukmè ir dažnumas, o IV — sèdejjimo trukmè per vieną dieną valandomis.

Vadovaujantis mokslo visuomenèje labiausiai pripažintomis ekspertu rekomendacijomis (Sallis et al., 1994; USDHHS, 1996; ACSM, 2002; National Association for Sport and Physical Education, 2003) ir pateikto tyrimo tikslu, straipsnyje analizuojami II ir IV anketos daliu rezultatai. Sveikata stiprinanti fizini aktyvumą (SSFA) patiriančiais buvo laikomi tie mokiniai, kuriu FA intensyvumas vidutinis, trukmè ne mažesnè kaip 60 minučių, dažnis - kiekvieną dieną. Kiti moksleiviai dèl nepakankamo fizinio aktyvumo turi galimybę patirti sveikatos sutrikimo rizikos grèsmę (WHO, 2003).

Visi tiriami moksleiviai supažindinti su tyrimo tikslu, anketos turiniu ir jos pildymo eiga. Anketinès apklausos metodas - interviu. Apklausiami tie moksleiviai, kurių tevai ir mokyklos administracija sutiko (leido) jiems dalyvauti tyrime.

Anketinę apklausą atliko penkios specialiai parengtos kvalifikuotuc tyrèjų grupès.

\section{Statistinès analizès metodai:}

- kintamujų dažnis ir procentai;

- kintamuju vidurkis;

- $t$ kriterijus (lyginant kiekybinio kintamojo vidurkius dviejose grupèse);

- chi kvadrato kriterijus (lyginant nominalinio arba ranginio kintamojo skirstinius dviejose ir daugiau grupiuc, tikrinant, ar yra dviejų nominaliniu arba nominalinio ir ranginio kintamojo statistinis ryšys);

- pasikliaunamieji intervalai (Vaitkevičius, Saudargienè, 2006);

- Spirmeno ranginès koreliacijos koeficientas (ivertinant dviejų ranginių kintamujų ryši);

- Somerio $d$ koeficientas.

Statistinė aprašomoji analizė atlikta naudojant SPSS ir Excel programas.

\section{REZULTATAI}

Išanalizavus 1636 moksleivių, gyvenančių Lietuvos didžiuosiuose miestuose, FA nustatyta (1 pav.), kad SSFA patiria tik mažuma moksleivių ir jis būdingesnis berniukams nei mergaitems (skirtumas statistiškai reikšmingas $-\chi^{2}=26,5$; $\mathrm{p}<0,001)$. Pasikliaunamieji intervalai (95\% patikimumo lygmeniu) berniuku grupeje yra $15,1-$ $22,1 \%$, mergaičiu $-7,7-11,8 \%$.

Analizuojant tiriamosios imties SSFA atskirose klasėse ( 2 pav.) nustatyta, kad skirtumas tiek tarp mergaičių, tiek tarp berniukų skaičiaus patiriančių SSFA grupèse pagal klases yra statistiškai nereikšmingas $(p>0,05)$. Išimtis - statistiškai reikšmingas skirtumas tarp 10 ir 11 klasės mergaičiu skaičiaus patiriančių SSFA grupejje $\left(\chi^{2}=8,26, p<0,01\right)$.

Analizuojant skirtingų Lietuvos didžiujų miestų mergaičių ir berniukų skirstinį SSFA grupèse (3 lent.), statistiškai reikšmingo skirtumo nenustatyta $(p>0,05)$. Mažiausiai (\%) mergaičių, patiriančių SSFA, gyvena Šiauliuose $(4,1 \%)$, kituose miestuose nuo $11,0-9,8 \%$; mažiausiai berniuku, patiriančiu SSFA (\%), gyvena Klaipėdoje (13,9\%), daugiausiai - Vilniuje $(22,4 \%)$.

Analizuojant patiriančių ir nepatiriančių SSFA mergaičiu (3 pav.) ir berniuku (4 pav.) fizinio pasyvumo (sėdejjimo) per dieną trukmę nustatyta, kad mergaičiu, kurioms būdingas SSFA, fizinio pasyvumo (sèdèjimo) per dieną trukmé yra mažesnè už mergaičių, kurios nepatiria SSFA. Skirtumas nedidelis, tačiau statistiškai reikšmingas (Somerio koeficientas $d=-0,088 ; p<0,001$ ). Tarp berniukų, patiriančių ir nepatiriančių SSFA, 
1 pav. Mokinių, patiriančių ir nepatiriančių su sveikata susijusị fizinị aktyvumą, skaičius
2 pav. Mergaičių ir berniukų skirstinys patiriančių SSFA grupèje pagal klases
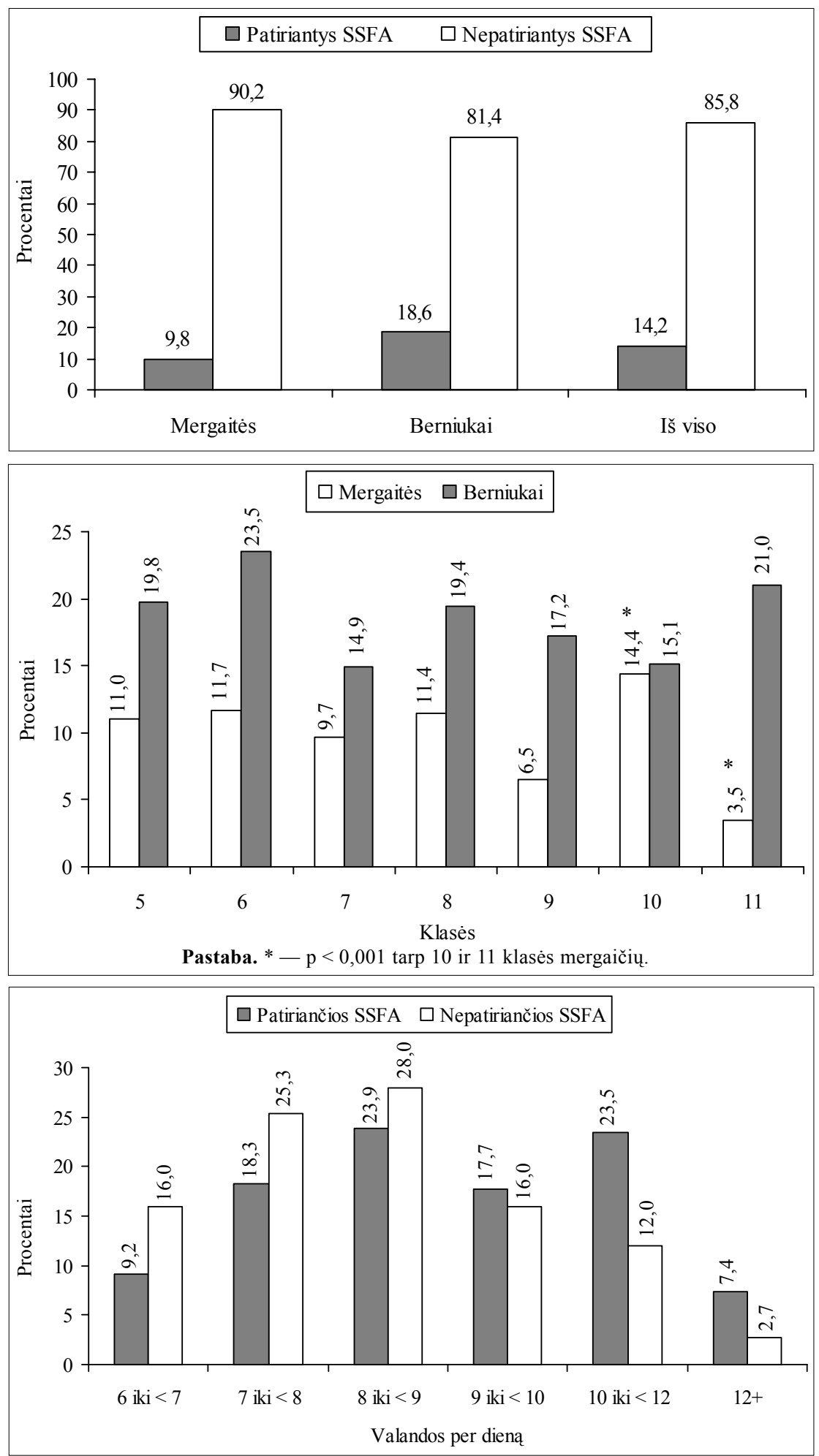

3 pav. Mergaičių, patiriančių ir nepatiriančių SSFA, fizinio pasyvumo (sėdèjimo) trukmè (h) per dieną

\section{REZULTATU APTARIMAS}

rodikliu skirtumas nenustatytas $(\mathrm{p}>0,05)$. Palyginus $t$ kriterijumi nesugrupuotą sèdejjimo laiko vidurki nustatyta, kad mergaičiu fizinio pasyvumo trukmė SSFA patiriančiu grupejje vidutiniškai yra 8,1 h / d., nepatiriančiuju $-8,8$ h / d. $(\mathrm{t}=3,39$; $\mathrm{p}<0,001)$; berniuku fizinio pasyvumo vidutine trukmè SSFA patiriančių ir nepatiriančiu grupèse - atitinkamai, 8,5 ir $8,6 \mathrm{~h} / \mathrm{d}$. $(\mathrm{p}>0,05)$.
Analizuojant gautus rezultatus nustatyta, kad mažumai Lietuvos moksleivių, iš jų labiau berniukams nei mergaitèms, yra būdingas fizinis aktyvumas, kurio intensyvumas, trukmè ir dažnumas stiprintų jų sveikatą. Nepakankamo fizinio aktyvumo paplitimas tarp i̇vairių šalių vaikų ir jaunimo, ypač tarp mergaičiuc, yra ganètinai dèsningas, dauguma iš 


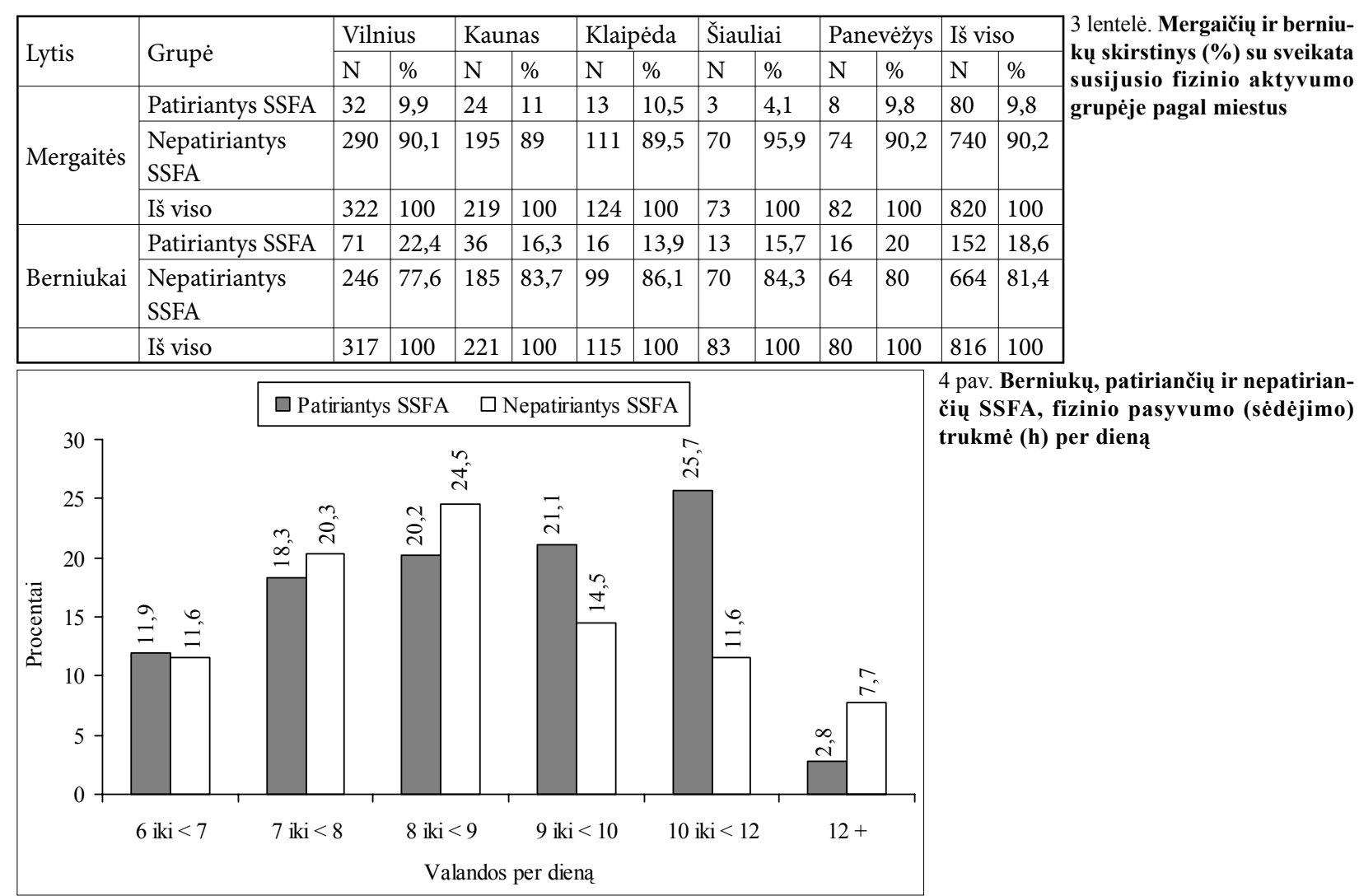

jų turi sveikatos rizikos veiksni dèl fizinio pasyvumo (Armstrong, Welsman, 1997; WHO, 2003; Westerstahl et al., 2004). Berniukai yra fiziškai aktyvesni nei mergaitès nuo ankstyvos vaikystès, tačiau 6-17 metų amžiaus tarpsniu fizinio aktyvumo skirtumas lyties grupèse yra pats didžiausias. Fizinio aktyvumo mažèjimas su amžiumi yra būdingas abiejose lyties grupèse, tačiau tarp mergaičiu jis yra 2,5 karto didesnis nei berniuku (Sallis, 1993). Skirtumo tarp berniukų ir mergaičių fizinio aktyvumo aiškinimas vien socialiniais ir aplinkos veiksniais yra pernelyg išpūstas (Armstrong, McManus, 1994). Didesnis berniukų fizinis aktyvumas gali būti susijęs su geresniu jų aerobiniu pajègumu, nors rezultatai apie aerobinio pajègumo ryšius su fiziniu aktyvumu yra preliminarūs. Berniukų struktūriniai ir funkciniai organizmo pokyčiai jiems augant ir bręstant (didesnis ūgis, didesnè kūno masè, labiau išlavèję raumenys, platesni pečiai, ilgesnès galūnès) suteikia jiems daugiau judejjimo galimybių ir leidžia būti fiziškai aktyvesniems (Branta et al., 1984). Literatūros šaltinių analizė rodo neigiamą koreliaciją tarp amžiaus ir bendrojo fizinio aktyvumo (Armstrong, Welsman, 1997), tačiau trūksta duomenų apie SSFA ir amžiaus koreliacinius ryšius. Tarptautinejje mokslinèje literatūroje nerandama atsakymo i klausimą, kaip koreliuoja moksleivių amžiaus ir SSFA rodikliai. Atlikto tyrimo metu nustatyta, kad su amžiumi, t. y. nuo 5 iki 11 klasès, moksleivių SSFA intensyvumas, tru- kmè ir dažnumas iš esmès nekinta. Tokiems rezultatams galèjo turèti itakos ir fizinio aktyvumo tyrimo metodologinès problemos, susijusios su moksleivių amžiaus nulemtu bendruoju išsilavinimu kūno kultūros srityje (pvz., žinių trūkumas apie FA reikšmę), kuris galejjo lemti ir „tinkamus“ respondentu atsakymus, t. y. apklausos rezultatų objektyvumą. Papildomi tyrimai apie skirtingo fizinio aktyvumo ir respondentų amžiaus koreliacinius ryšius galètu patikslinti kitų autorių ir mūsų tyrimų duomenis.

Kai kurios mokslinès studijos, neturèdamos pakankamai duomenų apie aplinkos veiksnių poveiki paaugliu fiziniam aktyvumui, hipotetiškai teigia, kad vaiku ir jaunimo fizinio pasyvumo plitimą gali lemti gyvenamojo miesto arba jo rajono fizinè aplinka, ribojanti paauglių fizinio aktyvumo galimybes (pvz., nèra žaliuju poilsio zonų, dviračių takelių, žaidimo aikštelių ir pan.), fizinio aktyvumo infrastruktūra mokykloje ir už jos ribų. Visgi labiausiai fizini aktyvumą gali lemti vaiko socialinis ekonominis statusas ir socialinė aplinka, ypač suaugusiuju fiziškai aktyvi elgsena (Sallis et al., 1992; Armstrong, Welsman, 1997; WHO, 2003). Gauti rezultatai apie skirtingu Lietuvos didžiujų miestų moksleivių SSFA statistiškai reikšmingai nesiskiria. Matyt, 5 tirtų miestų moksleivių fizinio aktyvumo raiškos galimybès yra ganètinai panašios.

Analizuojant moksleiviu fizinio pasyvumo (sẻdejimo) trukmę SSFA patiriančių ir nepatiriančių 
grupėse nustatyta, kad mergaičių, patiriančių SSFA, fizinio pasyvumo trukmé, nors ir nedaug, tačiau mažesnè nei nepatiriančiujų. Tarp berniukų fizinio pasyvumo trukmès reikšmingo skirtumo SSFA patiriančiu ir nepatiriančiu grupèse nenustatyta. Nustatyti fizinio aktyvumo lygio ir fizinio pasyvumo trukmès koreliaciniai ryšiai, tačiau, mokslinių tyrimu duomenimis, fizinio pasyvumo trukmė ne visuomet yra nepakankamo fizinio aktyvumo rodiklis ir, atvirkščiai (Biddle et al., 2004).

Tolesné FA tyrimu perspektyva, anot mokslininkų, - ieškoti efektyvių būdų vaikų sèdimos elgsenos problemoms spręsti. Taip pat būtina kuo greičiau spręsti ir šiuos klausimus: Kaip pagerinti mokinių fizini ugdymą, didinant jų fizini aktyvumą? Ar fizinio ugdymo programos yra patrauklios ir aktualios vaikams, jaunimui, ar skatina jų fizini aktyvumą laisvalaikiu? Kaip padidinti mokyklos, ypač kūno kultūros mokytojų, itaką sprendžiant fizinio pajejgumo ir aktyvumo problemas (Westerstahl et al., 2003; Wedderkoop et al., 2004)?

\section{IŠVADOS}

1. Iš viso SSFA patiria tik $14,2 \%$ Lietuvos didžiujų miestų 5-11 klasių moksleivių, o lyties grupèse $-9,8 \%$ mergaičiu ir $18,6 \%$ berniuku.
SSFA būdingesnis berniukams nei mergaitèms $(\mathrm{p}<0,001)$. Dél nepakankamo SSFA galimybę patirti sveikatos sutrikimo rizikos grèsmę turi $90,2 \%$ mergaičiu ir $81,4 \%$ berniukų, iš viso $85,8 \%$ moksleiviu (WHO, 2003).

2. Tiek mergaičių, tiek berniukų, patiriančiu su sveikata susijusi fizini aktyvumą, skirstiniai (\%) pagal klases statistiškai reikšmingai nesiskiria $(\mathrm{p}>0,05)$.

3. Tiek mergaičių, tiek berniukų, patiriančių su sveikata susijusį fizini aktyvumą ir gyvenančiu skirtinguose Lietuvos didžiuosiuose miestuose, skirstiniai (\%) statistiškai reikšmingai nesiskiria $(\mathrm{p}>0,05)$.

4. Mergaičių, kurioms būdingas SSFA, fizinio pasyvumo (sėdejjimo) per dieną trukmé, nors ir nedaug, bet yra mažesnè už mergaičių, kurios nepatiria SSFA $(p<0,001)$. Tarp berniuku patiriančių ir nepatiriančių SSFA, statistiškai reikšmingas jų fizinio pasyvumo trukmès rodiklių skirtumas nenustatytas $(\mathrm{p}>0,05)$.

Padẻka. Kūno kultūros ir sporto departamentui prie Lietuvos Respublikos Vyriausybès už suteiktą finansinę paramą igyvendinant ši projektą, LKKA Sporto edukologijos fakulteto studentams, savanoriškai padejusiems vykdyti projektą.

\section{LITERATŪRA}

ACSM. (2002). How much exercise is enough? Sports Medicine Bulletin, 37, 6, 5-6.

Ainsworth, B. E., Levy, S. S. (2004). Assessment of health-enhancing physical activity: methodological issues. In P. Oja, J. Borms, (Eds.), Health Enhancing Physical Activity. Perspectives - the Multidisciplinary Series of Physical Education and Sport Science, 6 (pp. 239-270). Oxford (UK): Meyer\&Meyer Sport Ltd.

Andersen, L., Mechelen,W. (2005). Are children of today less active than before and is their health in danger? What can we do? Scandinavian Journal of Medicine \& Science in Sports, 15 (5), 268-270.

Armstrong, N., McManus, A. (1994). Children's fitness and physical activity - a challenge for physical education. British Journal of Physical Education, 25, 20-26.

Armstrong N., Welsman, J. (1997). Young People \& Physical Activity. Oxford (UK): University Press.

Barnekow-Bergkvist, M., Hedberg G., Janlert, U., Jansson, E. (2001). Adolescent determinants of cardiovascular risk factors in adult men and women. Scandinavian Journal of Public Health, 29, 208-217.

Barnekow-Bergkvist, M., Hedberg, G.., Janlert, U., Jansson, E. (1998). Determinants of self-reported neck-shoulder and low back symptpms in a general population. Spine, 23, 235-243.

Biddle, S., Gorely, T., Marshall, S. J., Murdey, I., Cameron, N. (2004). Physical activity and sedentary behaviors in youth: issues and controversies. Journal of the Royal
Society of Health, 124 (1), 29-33.

Branta, C., Haubenstricker, J., Seefeldt, V. (1984). Age changes in motor skills during childhood and adolescence. Exercise and Sport Sciences Reviews, 12, 467-520.

Casperson, C. J., Nixon, P. A., DuRant, R. H. (1998). Physical activity epidemiology applied to children and adolescents. Exercise and Sport Sciences Reviews, 26, $341-403$.

Corbin, Ch. B., Masurier, G. L., Franks, B. D. (2002). Making sense of multiple physical activity recommendations. President's Council on Physical Fitness and Sports. Research Digest, Series 3, 19.

Hardman, A. E. (2001). Physical activity and health: Current issues and research needs. International Journal of Epidemiology, 30, 5, 1193-1197.

Katzmarzyk, P. T., Malina, R. M., Bouchard, C. (1999). Physical activity, physical fitness, and coronary heart disease risk factors in youth: The quebec family study. Prev Med, 29, 555-562.

National Association for Sport and Physical Education. (2003). Physical Activity and Children: A Statement of Guidelines. Reston. VA: NASPE.

Oja, P., Borms, J., ed. (2004). Health enhancing physical activity. Perspectives - the Multidisciplinary Series of Physical Education and Sport Science, 6, 465. Oxford (UK): Meyer\&Meyer Sport Ltd.

Rankinen, T., Bouchard, C. (2002). Dose-response issues concerning the relations between regular physical activity 
and health. President's Council on Physical Fitness and Sports Research Digest, 3 (18).

Sallis, J. F. (1993). Epidemiology of physical activity and fitness in children and adolescents. Critical Reviews of Food Science and Nutrition, 33, 403-408.

Sallis, J. F., Patrick, K., Long, B. L. (1994). An overview of international consensus on physical activity guidelines for adolescents. Pediatric Exercise Science, 6, 299-301.

Sallis, J. F., Simons-Morton, B. G., Stone, E. J. et al. (1992). Determinants of physical activity and interventions in youth. Medicine \& Science in Sports \& Exercise, $24,6,248-257$.

USDHHS. (1996). Physical Activity and health: A Report of the Surgeon General. Atlanta. GA: U.S. Department of Health and Human Services, Centers for Disease Control and Prevention, National Center for Chronic Disease Prevention and health Promotion.

Vaitkevičius, R., Saudargienè, A., (2006). Statistika su SPSS psichologiniuose tyrimuose. Statistika socialiniuose moksluose: mokomoji knyga. Kaunas: VDU. P. 224.
Wedderkoop, K., Froberg, K., Hansen, H. S., Andersen, L. B. (2004). Secular trends in physical fitness and obesity in Danish 9-year-old girls and boys: Odense School Child study and Danish substudy of the European Youth Heart Study. Scandinavian Journal of Medicine \& Science in Sports, 14, 150-155.

Westerstahl, M., Barnekow-Bergkvist, M., Hedberg, G., Jansson, E. (2003). Secular trends in body dimensions and physical fitness among adolescents in Sweden from 1974 to 1995. Scandinavian Journal of Medicine \& Science in Sports, 13, 128-137.

Westerstahl, M., Barnekow-Bergkvist, M., Jansson E. (2004). Low physical activity among adolescents in practical education. Scandinavian Journal of Medicine \& Science in Sports, 15, 287-297.

World Health Organization. (2003). Anual Global Move for Health Initiative: a Concept Paper. Geneva, Switzerland.

Гудвин, Д. (2004). Исследование в психоллогии: методы и планирование. Санкт-Петербург.

\title{
HEALTH-RELATED PHYSICAL ACTIVITY OF 5-11 ${ }^{\mathrm{TH}}$ GRADE STUDENTS FROM LITHUANIAN CITIES
}

\author{
Vida Volbekienė, Aušra Griciūtè, Aida Gaižauskienè \\ Lithuanian Academy of Physical Education, Kaunas, Lithuania
}

\begin{abstract}
Research aim was to establish the spread of health-related physical activity among the $5-11^{\text {th }}$ grade students living in Lithuanian cities.

The research was carried out in April, 2005, in five Lithuanian cities (Vilnius, Kaunas, Klaipėda, Šiauliai, and Panevėžys). The sample size in the gender and age groups of $11-18$ year old students was calculated according to the data of Lithuanian population census of 2001. The schools were selected at random. The students according to the grades at schools were selected applying the convenience sampling. Thus, the sample for the analysis of health-related fitness consisted of 1636 students.

Physical activity (PA) of students was established using the modified international physical activity questionnaire (IPAQ). Students experiencing health enhancing physical activity were those who were involved in moderate physical activity, the duration of which was 60 minutes, and the frequency - every day. Due to insufficient physical activity other students were at risk of being in poor health $(W H O, 2003)$. The questionnaire survey was carried out by five groups of researchers with special qualifications.

Methods of statistical analysis: frequency and percentage of variables, means of variables, standard deviations, t criterion, chi square criterion, confidence intervals, Spearman's correlation coefficient of ranks, Somers's d coefficient. Statistical analysis was performed using SPSS and Excel programs.

Conclusions: Health-related physical activity (HRPA) was experienced only by $14.2 \%$ at all of $5-11^{\text {th }}$ grade students living in Lithuanian cities; in gender groups - 9,8\% girls and 18,6\% boys. HRPA was more common among boys than girls $(\mathrm{p}<0.001)$. Due to insufficient physical activity $85.8 \%$ of students were at risk to have health problems, $90.2 \%$ of them were girls, and $81.4 \%$ were boys WHO, 2003). Among those students who were involved in sufficient health-related physical activity, both boys and girls' distributions in grades did not differ statistically significantly. Neither did the distributions in different Lithuanian cities. The duration of physical passiveness (sitting) was shorter, though very slightly, of girls involved in HRPA, compared to those girls, who were not involved in HRPA. No statistically significant differences were established in the duration of physical passiveness of boys who were and who were not involved in HRPA.
\end{abstract}

Keywords: health-related physical activity, physical activity, physical inactivity.

Gauta 207 m. sausio 29 d.

Received on January 29, 2007

Priimta $2007 \mathrm{~m}$. balandžio $24 \mathrm{~d}$.

Accepted on April 24, 2007
Vida Volbekienè

Lietuvos kūno kultūros akademija

(Lithuanian Academy of Physical Education)

Sporto g. 6, LT-44221 Kaunas

Lietuva (Lithuania)

Tel +370 37302669

E-mail v.volbekiene@lkka.lt 